\title{
Potential effects of sediment contaminants on diatom assemblages in coastal lagoons of New Jersey and New York States
}

Marina Potapova ${ }^{\mathrm{a}, \mathrm{b}^{*}}$, Nina Desianti ${ }^{\mathrm{a}}$, Mihaela Enache ${ }^{\mathrm{c}}$

${ }^{a}$ Department of Biodiversity, Earth and Environmental Science, Drexel University, Philadelphia, PA 19104, United States

${ }^{\mathrm{b}}$ Academy of Natural Sciences, Drexel University, Philadelphia, PA 19103, United States

${ }^{c}$ New Jersey Department of Environmental Protection, Trenton, NJ 08608, United States

*Corresponding author

\begin{abstract}
Sediment samples from the coastal lagoons and estuaries of New York and New Jersey were used to investigate the influence of contaminants on diatom assemblages. Multivariate analyses demonstrated correspondence between composition of diatom assemblages and concentrations of several metals and total PAH. The effects of the individual contaminants were difficult to disentangle because of the considerable correlations between their concentrations. The most conspicuous trend was the increase in the relative abundance of small centric planktonic diatoms in response to contamination and the corresponding decrease in the benthic flora. The high relative abundance of planktonic species on contaminated sediments apparently resulted not so much from their tolerance to pollution, but from the paucity of benthic species. A comparison of the assemblages on the surface and at the depth of approximately $8-10 \mathrm{~cm}$ revealed a statistically significant temporal change in community composition towards planktonic diatoms.
\end{abstract}

\section{Keywords}

Diatoms; metals; New Jersey; New York; PAH; sediments

\section{Introduction}

Diatoms are commonly used as indicators of various environmental characteristics, especially salinity, $\mathrm{pH}$, and nutrients (Smol and Stoermer, 2010). Diatoms are also known to be sensitive to toxic substances, such as metals (Cattaneo et al., 2008, Duong et al., 2008; Morin et al., 2012) and organic contaminants (Moisset et al., 2015). Classic toxicological approaches, such as testing the effects of contaminants on single species or monoclonal cultures in the laboratory conditions demonstrated effects of individual contaminants and of their mixtures on both freshwater (e.g., Adams and Stauber, 2004; Araujo et al., 2010; Larras et al., 2012,) and marine (e.g., Fan and Reinfelder, 2003; Hagenbuch and Pinkney, 2012; Joux-Arab et al., 2000; Moreno-Garrido et al., $2003,2007)$ diatoms. While the traditional tests typically measured growth or survival rates of various species depending on the dosage and length of the exposure to contaminants, a number of recent studies attempted to investigate mechanisms of toxicity by estimating gene expression (Kim Tiam et al., 2012; Moisset et al., 2015) and enzyme activities indicating which cell 
functions are affected (Bonet et al., 2012; Crespo et al., 2013). Laboratory and field experiments were also crucial for investigating effects of contaminants on the composition (Morin et al., 2010; Ricart et al., 2010) and diversity (Ricciardi et al., 2009) of algal communities and the function of the river biofilm ecosystems (Barral-Fraga et al., 2015). Several researchers used mesocosms and artificial streams to study freshwater diatom community composition changes in response to contaminant exposure (Pérès et al.,1997; Gold et al., 2003; Kim Tiam et al., 2015). Ivorra et al. (1999) and Morin et al. (2014) documented the effect of zinc exposure on lotic diatom communities using in situ translocation experiments. While experimental work is indispensable for establishing causal relationships between pollutants and organisms, field surveys are important for detecting potential effects of contaminants on whole communities in situ and for observing the ecosystem-level effects. Cattaneo et al. $(2004,2008)$ showed how diatom community composition changed with time as a result of metal pollution in several Canadian lakes with sensitive planktonic species declining in abundance and more tolerant benthic species surviving heavy pollution. Medley and Clements (1998) combined field observations with experiments to study the effects of metals on diatom community composition in Colorado streams and determined which diatom species were either sensitive or tolerant to various metals. The effects of contaminants on the species composition and diversity of benthic algae including diatoms were demonstrated in field studies of rivers in Spain (Sabater, 2000; Guasch et al., 2009; Brix et al., 2012) and in Northern Canada (Spencer et al., 2008). In comparison to freshwaters, relatively little is known about patterns of benthic diatom distribution in relation to sediment contaminants in marine environment. The effects of hydrocarbons and metals on subtidal sediment diatom assemblages were studied in Antarctica using field survey (Cunningham et al., 2005) as well as field experiments (Cunningham et al., 2003). In the temperate zone no field studies of subtidal diatom assemblages along gradients of contaminants have been done yet.

The present investigation is an attempt to reveal potential effects of contaminants on diatoms in surface sediments in the coastal waters of New York and New Jersey. This investigation is part of a survey aimed at assessing the presence of sediment contaminants after Hurricane Sandy and their effects on biota conducted by USGS in 2013. Unfortunately, no baseline data on spatial and temporal variation of surface sediment diatom assemblages in the area was available. The closest location where diatoms from sediment core samples have been analyzed was conducted in Long Island Sound (Cooper et al., 2010; Varecamp et al., 2010). An increase of planktonic to benthic diatom ratio and a decrease in species diversity and abundance of diatoms starting from 1850s was reported, but detailed data on species composition in Long Island Sound samples have yet to be published. Our study is thus the first report on the patterns of distribution of subtidal sediment diatoms in the near-shore locations of New York and New Jersey and their possible links to contaminants.

\section{Materials and methods}

\subsection{Study area, sampling, and laboratory analyses}

Surface sediment samples were collected from 50 sites in the lagoons and estuaries along the Atlantic coastline in New York and New Jersey, from Cape May, NJ and along the southern shore of Long Island to its eastern end (Fig. 1). The samples were collected by USGS and 
USEPA staff in June-October 2013 as part of the USGS post-Hurricane Sandy assessment of sediment contaminants. The samples were collected from boats using Ekman, Petite Ponar, or Van Venn grab samplers. The upper top $2 \mathrm{~cm}$ of the each grab sample was analyzed for grain size, contaminants and diatoms, while only diatom subsamples were collected from the base of the grab samples. All analytical methods used to determine contaminant concentrations, TOC and particle size of the sediments are described in Fischer et al. (2015) and were performed by the USGS staff. Surface water salinity data were collected by various agencies and retrieved from Water Quality Data Portal (http://waterqualitydata.us/).

About $1 \mathrm{~g}$ of wet sediment from each sediment sample was used for diatom sample processing. The organic component was oxidized with $70 \%$ nitric acid while heated for $1.5 \mathrm{~h}$. Diatoms were repeatedly allowed to settle for 24 hours and the supernatant was decanted until it reached a neutral $\mathrm{pH}$. A measured amount of digested sample was dripped onto a microscope cover slip and dried. Cover slips were then mounted onto slides using a high refractive index mounting medium (Naphrax ${ }^{\mathrm{TM}}$ ). Diatoms were counted and identified using a Nikon Eclipse 80i microscope equipped with DIC optics. Five hundred valves were counted for each slide at 1000x magnification. For Scanning Electron Microscopy (SEM) diatom suspensions were air-dried on aluminum stubs. The samples were then sputter-coated with Pt-Pd and observed with a Zeiss Supra 50 scanning electron microscope under $10 \mathrm{kV}$ accelerating voltage.

\subsection{Data analyses}

Among various contaminants analyzed in the samples sediments, we chose metals and polycyclic aromatic hydrocarbons (PAHs) to investigate as potential stressors affecting diatom assemblages. The reason that other parameters, such as PCBs, were excluded from this study was that they comprised a relatively high number of non-detects in the dataset. In addition to individual concentration of metals and PAH species, we used two summary variables. The first represented the sum of all PAH species (total PAH). A summary variable reflecting the toxicity of metals was constructed based on the same principle that was used by Clements et al. (2000) to study response of biota to multiple metal contamination in rivers. Clements et al. (2000) suggested using a summary variable, which they called the "compound variable cumulative criterion unit", or CCU. To calculate CCU, it first necessary to calculate the ratio of each observed metal concentration to the concentration known to cause negative effects on invertebrates. The sum of all calculated ratios is the CCU. Such summary variables were subsequently applied to evaluate the effect of toxic substances on freshwater diatom assemblages by Morin et al. (2012) and Guasch et al. (2009). While Clements et al. (2000) used critical values of water concentrations of metals, we use here the sediment concentrations and the sediment quality guidelines published by Long et al. (1995), who summarized a large number of studies of the impact of sediment contaminants on aquatic invertebrates. Two concentrations for nine metals ( $\mathrm{As}, \mathrm{Cd}, \mathrm{Cr}, \mathrm{Cu}$, $\mathrm{Pb}, \mathrm{Hg}, \mathrm{Ni}, \mathrm{Ag}$ and $\mathrm{Zn}$ ) provided by Long et al. (1995) are called Effect Range-Low (ERL) and Effect Range-Medium (ERM). These thresholds correspond to the $10 \%$ and $50 \%$ incidence of toxic effects the corresponding metals on invertebrates. The ERL is used here because the largest majority of observations were below the ERM level. The variable that we call CCU following Clements et al. (2002), is calculated as $C C U=\Sigma\left(m_{i} / E R L_{i}\right)$, where $m_{i}$ is the concentration of each metal and ERL is its Effects Range-Low level as given by Long et al. (1995). The particle or grain size is represented by a single variable, which is the sum of sand and gravel percentages. 
To explore the structure of contaminant data used in this study, the Principal Component (PCA) analysis was used. The values of environmental variables were standardized. Detrended Correspondence Analysis (DCA) was carried out to identify major gradients in diatom data and to relate them to measured environmental parameters, such as contaminants, sediment particle size, total organic carbon (TOC), and water salinity. To test the significance of the contaminants' effect on diatom assemblages, a series of partial Canonical Correspondence Analyses (CCA) with Monte Carlo permutation tests were carried out. Environmental variables that are known to be important determinants of diatom assemblage composition, such as salinity, grain size and total organic carbon (TOC) were used as covariates in CCAs to ensure that only the portion of variability on diatom data attributable to contaminants is estimated. An option of "downweighting of rare species" was chosen in DCA and CCA analyses. To test for differences in diatom assemblage composition between top and bottom sediment layer samples we used a partial redundancy analysis (RDA). Sampling sites were used as covariates to control for the effect of the site. Species relative abundances were square-root transformed in all ordinations, which were carried out using CANOCO version 5.0 (Ter Braak and Šmilauer, 2012).

Indicator species analysis (ISA, Dufrêne and Legendre, 1997) was utilized to determine which diatom species may serve as the best indicators of relatively low or high contaminant levels is the studied area. Nine metals that were combined into CCU variable as described above and the total PAH concentration were used as environmental variables. Two groups of samples were used in each analysis; the threshold for dividing the groups was the average concentration of the contaminant. Species with the highest indicator values in the high- or low-concentration groups were considered as indicators of relatively high or low levels of contaminants. ISA were carried out with PC-ORD version 6 program (McCune and Mefford, 2011).

\section{Results}

\subsection{Environmental data.}

The average values and ranges of variation of some environmental parameters measured for 50 surface sediment samples used in this study are shown in Table 1.

A strong correlation structure was observed in the contaminant data, which makes it difficult to separate the effects of individual parameters on biological communities. The PCA of all environmental variables measured in 50 "top" samples revealed that various species of PAHs were highly correlated (Fig. 2), and therefore a single composite variable (total PAH) could be used in further analyses. PAH concentrations were negatively correlated with salinity. Metals were also correlated among themselves, but not as strongly as PAHs (Fig. 2). Metal concentrations were also positively correlated with TOC and negatively with grain size.

\subsection{Diatom assemblages.}

A total of 398 diatom taxa were found in 100 samples used in this study. The taxa with the highest number of occurrences were Planothidium delicatulum (Kützing) Round and Bukhtiyarova (94 samples), Cocconeis neothumensis var. marina DeStefano et al. (90), 
Cyclotella atomus var. gracilis Genkal et al. (87) and Navicula perminuta Grunow (87), diatoms commonly reported from brackish and marine coastal waters. Many taxa could not be identified to species level: they require additional taxonomic treatment and may well represent species new to science. Among taxa that have not yet been reported from the coast of New York and New Jersey, we found representatives of the genus Minidiscus: M. comicus Takano and M. spinulosus Gao et al. These diatoms were 2-4 $\mu \mathrm{m}$ in diameter and not identifiable to species level in LM. The genus Chaetoceros was mostly represented by spores and very small vegetative cells: no attempt was made to identify Chaetoceros representatives to species level. Likewise, species within Skeletonema costatum (Greville) Cleve group could not be separated with LM and were reported here as Skeletonema spp.

An exploratory DCA analysis was carried out with diatom data from the 50 "top" samples (Fig. 3 ). The analysis revealed that the first DCA axis corresponds to the gradient in diatom data from coarse-grained to fine-grained sediments. Species in the left part of the diagram were mostly epipsammic diatoms, such as small-celled Amphora sp. 1, Amphora sp. 2, Fallacia amphipleuroides (Hustedt) Mann and F. margino-punctata Sabbe \& Vyverman, associated with relatively coarse-grained sediments. Species that were most abundant on fine-grained silty sediments appeared on the right part of the diagram. Besides some epipelic Navicula species, they included a number of planktonic diatoms, which are likely accumulating on the bottom by sinking from the water column. An overlay of the vectors representing environmental variables on the DCA plot (Fig. 3) revealed a considerable collinearity among most environmental parameters, which makes it difficult to separate their effects on diatom assemblages. Metals, PAHs, and TOC were positively correlated with the amount of fine-grained sediments. The second DCA axis was correlated with the salinity gradient, which typically appears as a very strong determinant of diatom assemblage composition in estuarine environments.

\subsection{Effect of contaminants.}

CCA analyses were carried out with various contaminant variables as constraints, while salinity, sediment grain size and TOC were used as covariates. Although salinity did not show a strong collinearity in DCA (Fig.3), it was moderately correlated with PAHs and some metals (Fig.2), and therefore, its effect had to be taken into account when testing for the effect of contaminants.

A CCA in which summary contaminant variables, CCU and PAH were used as constraints (Fig. 4), demonstrated that contaminants explained a statistically significant portion of variation in diatom species data: constrained axes were significant at $\mathrm{p}=0.047$. Both variables together explained $5.5 \%$ variation in species data.

CCA analyses with individual metal and PAH species concentrations, $\mathrm{CCU}$, and total PAH as single constraining variables were used to test for the significance of the effects of these factors. Table 2 shows the proportion of explained variance on species data attributed to each of these variables. Only seven metals listed in Table 1 had an effect supported by the p-value below 0.01 , but if corrected for multiple correlations by applying the Bonferroni correction to the whole set of 49 explanatory variables (metals and PAHs), only Tl, Co, and Sr appeared to have a significant effect at $\mathrm{p}=0.01$. It is necessary to point out that no conclusion should be made at 
this point about the effect of individual contaminants as some of the apparently highly significant relationships may be spurious considering strong correlations between individual contaminants.

The results of ISA (Table 3) show that diatoms identified as the best indicators of high or low contaminant levels were often the same species for many parameters, which is obviously due to strong inter-correlations in the contaminant data. Sensitive species included mostly epipsammic diatoms from Amphora, Cocconeis, Plantohidium, and Fallacia genera. Species associated with high amount of sediment contaminants were mostly small planktonic taxa, especially Cyclotella atomus Hustedt, C. marina (Tanimura et al) Ake-Castillo et al., and Chaetoceros spp., but some benthic diatoms, such as Navicula gregaria Donkin and Nitschia sp. 3 also were members of the "tolerant" group.

\subsection{Temporal change in diatom assemblages}

The partial RDA analysis revealed a highly significant difference in the composition of the diatom assemblages between top and bottom sediment layers. The first RDA axis constrained to the "top-bottom" variable was highly significant at $p=0.001$. Fig. 5 shows the most abundant species in the whole dataset and their scores along the first RDA axis plotted against their average relative abundance. Species in the left part of the plot are those with maximum abundance in the "bottom" samples, while those on the right had higher abundances in the "top" samples. Green triangles indicate species that were determined as sensitive to contaminants by the ISA: most of these diatoms are also characteristic for the "bottom" samples. Species indicated by the red stars were determined as tolerant to contaminants by the ISA; their abundances mostly increased in the "top" samples as compared to "bottom" samples. Our data, therefore, demonstrate a temporal trend towards pollution-tolerant taxa.

\section{Discussion}

We found two important relationships: a correspondence between contaminants and diatom distribution on surface sediments and a temporal trend towards increased abundance of small pollution-tolerant planktonic diatoms. Since no previous studies investigated the correspondence between surface sediment diatoms and contaminants in the shallow coastal areas in temperate zone, it is difficult to say if the pattern of diatom distribution in relation to contaminant concentrations that we found in New York and New Jersey is typical for this type of environment. In a study carried out in Antarctica, sediment diatom assemblages were dominated by benthic species and a clear shift in the species composition of benthic diatoms along the gradient of metal contamination was found (Cunningham et al., 2005). In our study, small planktonic species were often dominant diatoms on surface sediments, especially in the heavily contaminated sites, while benthic diatoms were scarce in the most contaminated localities. The effect of contaminants on benthic species was thus not especially pronounced in our study. The range of variation in metal concentrations was somewhat higher in our study compared to 
Cunningham et al. (2005), so there are reasons to believe that sediment contamination is at least a partial reason for the decline of benthic diatoms in the most polluted sites.

The problem is, however, in the difficulty of separating the effect of contaminants from other factors, especially eutrophication. Changes towards the dominance of small planktonic diatoms on surface sediments in recent decades have been reported from many nutrient-enriched coastal areas around the World (Andrén, 1999; Andrén et al., 2000; Lesniewska and Witak, 2011; Rabalais et al., 1996; Katsuki et al., 2009; Wekström \& Juggins, 2006), including Long Island Sound (Cooper et al., 2010; Varecamp et al., 2010). In Chesapeake Bay small planktonic diatom Cyclotella chocktawatcheeana Prasad started increasing in abundance already from early $1800 \mathrm{~s}$ (Cooper, 1995). Some extremely small planktonic diatoms identified as tolerant to contaminants in our study, such as Cyclotella atomus, are also known to have high nutrient optima (Wekström and Juggins, 2006). As it can be seen in Fig. 5, not all centric diatoms that increased in abundance with time in our study area were found to tolerate high levels of contaminants. For example, Minidiscus spp., which was more abundant in top samples, was not indicative of contamination. Some species of Minidiscus spp. are known to be associated with upwellings (Buck et al., 2008), and thus may benefit from increased nutrients. Nutrients were not analyzed in this study, and therefore, it was impossible to compare effects of nutrients and contaminants. The highest concentrations of contaminants were observed in this study in estuaries of small rivers, such as Navesink R. and Shrewsbury R., where nutrient concentrations were also likely to be high. It is possible, therefore, that increased nutrients in water column stimulated summer blooms of planktonic diatoms and benthic diatoms were shaded by plankton. Planktonic diatoms found in sediment samples, in this case are the cells settled from the water column.

On the other hand, a few benthic diatoms increased in abundance with contamination. This may serve as an indication that shading by plankton was not the only reason for the decline of many benthic species in heavily contaminated sites. Navicula gregaria, is known, for instance as highly tolerant to various types of pollution (Lange-Bertalot, 1979). In general, representatives of the genus Navicula are often abundant in polluted waters, including subtidal marine environments (Cibic et al., 2008; Cunningham, 2005).

In summary, our findings indicate a possible influence of toxic compounds on sediment diatom assemblages with some species declining and others increasing in relative abundance along the gradient of contamination. At the same time, as it is often the case with field surveys, it is difficult to separate the effects of inter-correlated environmental factors on biological assemblages. Experimental studies will be necessary to determine causal relationships and ultimately to develop better guidelines for the aquatic life protection.

Funding sources

This study was funded by U.S. Geological Survey as part of a project evaluating the effect of the Hurricane Sandy on presence and distribution of contaminants

\section{References}


Adams, M.S. \& Stauber, J.L. 2004. Development of a whole-sediment toxicity test using a benthic marine microalga. Environmental Toxicology and Chemistry 23: 1957-1968.

Andrén, E. 1999. Changes in the composition of the diatom flora during the last century indicate increased eutrophication of the Oder estuary, south-western Baltic Sea. Estuarine, Coastal and Shelf Science 48: 665-676.

Andrén, E., Andrén, T., \& Kunzendorf, H. 2000. Holocene history of the Baltic Sea as a background for assessing records of human impact in the sediments of the Gotland Basin. The Holocene 10: 687-702.

Araújo, C.V.M., Blasco, J. \& Moreno-Garrido, I. 2010. Microphytobenthos in ecotoxicology: A review of the use of marine benthic diatoms in bioassays. Environment International 36: 637646.

Barral-Fraga, L., Morin S, Rovira MD, Urrea G, Magellan K, Guasch H. 2015. Short-term arsenic exposure reduces diatom cell size in biofilm communities. Environmental Science and Pollution Research, DOI 10.1007/s11356-015-4894-8.

Bonet, B,. Corcoll, N., Tlili, A., Morin S. \& Guasch H., 2012. Antioxidant enzyme activities in biofilms as biomarker of $\mathrm{Zn}$ pollution in a natural system: an active bio-monitoring study. Ecotoxicology and Environmental Safety 103:82-90.

Brix, R., López-Doval, J., Ricart, M., Guasch, H., de Alda, M.L., Muñoz, I., Orendt, C., Romaní, A.M., Sabater, S. \& Barceló, D. 2012. Establishing potential links between the presence of alkylphenolic compounds and the benthic community in a European river basin. Environmental science and Pollution Research International 19: 934-45.

Brush, G. S. \& Davis, F. W. 1984. Stratigraphic evidence of human disturbance in and estuary. Quaternary Research 22: 91-108.

Buck, K.R., Chavez, F.P. \& Davis, A.S. 2008. Minidiscus trioculatus, a small diatom with a large presence in the upwelling system of Central California. Nova Hedwigia, Beihefte 133: 1-6.

Cattaneo, A, Couillard, Y.\& Wunsam, S. 2008. Sedimentary diatoms along a temporal and spatial gradient of metal contamination. Journal of Paleolimnolimnology 40:115-127.

Cattaneo A, Couillard Y, Wunsam S, Courcelle M. 2004. Diatom taxonomic and morphological changes as indicators of metal pollution and recovery in Lac Dufault (Québec, Canada). Journal of Paleolimnolimnology 32:163-175.

Cibic, T., Acquavita, A., Aleffi, F.,Bettoso, N., Blasutto, O., De Vittor, C., \& Falconi, C. 2008. Integrated approach to sediment pollution: A case study in the Gulf of Trieste. Marine pollution bulletin 56: 1650-1657.

Clements, W.H., Carlisle, D.M., Lazorchak' J.M. \&. Johnson, P.C. 2000. Heavy metals structure benthic communities in Colorado mountain streams. Ecological Applications 10:626-638. 
Cooper, S. R. 1995a. Chesapeake Bay watershed historical land use: impact on water quality and diatom communities. Ecological Applications 5: 703-723.

Cooper, S.R. 1995b. Diatoms in sediment cores from the mesohaline Chesapeake Bay, U.S.A. Diatom Research 10: 39-89.

Cooper, S.R. \& Brush, G.S. 1991. Long term history of Chesapeake Bay anoxia. Science 254, 992-996.

Cooper, S.R. and Brush, G.S. 1993. A 2,500-year history of anoxia and eutrophication in Chesapeake Bay. Estuaries 16: 617-626.

Cooper, S. R., Gaiser, E. \& Wachnicka, A. 2010. Estuarine paleoenvironmental reconstructions using diatoms. In Smol, J \& Stoermer, E.F. (Eds.), The diatoms: applications for the environmental and earth sciences. Cambridge Uiversity Press, Cambridge, pp325-345

Crespo, E., Lozano, P., Blasco, J. \& Moreno-Garrido, I. 2013. Effect of copper, irgarol and atrazine on epiphytes attached to artificial devices for coastal ecotoxicology bioassays. Bulletin of environmental contamination and toxicology 91: 656-660.

Cunningham, L.O., Raymond, B., Snape. I. \& Riddle, M.J. 2005. Benthic diatom communities as indicators of anthropogenic metal contamination at Casey Station, Antarctica. Journal of Paleolimnology 33: 499-513.

Cunningham L., Stark, J.S., Snape I., McMinn, A. \& Riddle, M.J. 2003. Effects of metal and petroleum hydrocarbons on benthic diatom communities near Casey Station, Antarctica: an experimental approach. Journal of Phycology 39: 490-503.

Dufrêne, M. \& Legendre, P. 1997. Species assemblages and indicator species: the need for a flexible assymetrical approach. Ecological Monographs 67: 345-366.

Duong, T.T., Morin, S., Herlory, O., Feurtet-Mazel, A., Coste, M. \& Boudou, A. 2008. Seasonal effects of cadmium accumulation in periphytic diatom communities of freshwater biofilms. Aquatic Toxicology 90: 19-28.

Fan, C.-W. \& Reinfelder, J.R. 2003. Phenanthrene accumulation kinetics in marine diatoms. Environmental Science and Technology 37: 3405-3412.

Fischer, J.M., Phillips, P.J., Reilly, T.J., Focazio, M.J., Loftin, K.A., Benzel, W.M., Jones, D.K., Smalling, K.L., Fisher, S.C., Fisher, I.J., Iwanowicz, L.R., Romanok, K.M., Jenkins, D., Bowers, L., Boehlke, A., Foreman, W.T., Deetz, A.C., Carper, L.G., Imbrigiotta, T.E., \& Birdwell, J., 2015. Estuarine bed-sediment-quality data collected in New Jersey and New York after Hurricane Sandy, 2013: U.S. Geological Survey Data Series 905, 42 p., http://dx.doi.org/10.3133/ds905 
Guasch, H., Leira, M., Montuelle, B., Geiszinger, A., Roulier, J.L., Tornés, E. \& Serra, A. 2009. Use of multivariate analyses to investigate the contribution of metal pollution to diatom species composition: search for the most appropriate cases and explanatory variables. Hydrobiologia 627: $143-158$.

Hagenbuch, I.M. \& Pinckney, J. L. 2012. Toxic effect of the combined antibiotics ciprofloxacin, lincomycin, and tylosin on two species of marine diatoms. Water Research 46:5028-5036.

Ivorra, N., Hettelaar, J., Tubbing, G. M. J., Kraak, M. H. S., Sabater, S. \& Admiraal, W. 1999. Translocation of Microbenthic Algal Assemblages Used for In Situ Analysis of Metal Pollution in Rivers. Archives of Environmental Contamination and Toxicology 37: 19-28.

Joux-Arab, L., Berthet, B. \& Robert, J. -M. 2000. Do toxicity and accumulation of copper change during size reduction in the marine pennate diatom Haslea ostrearia? Marine Biology 136: 323-330.

Katsuki, K., Seto,K., Nomura, R., Maekawa,K., \& Khim ,B.-K. 2009. Effect of human activity on Lake Saroma (Japan) during the past 150 years: Evidence by variation of diatom assemblages. Estuarine, Coastal and Shelf Science 81: 215-224.

Kim Tiam, S., Feurtet-Mazel, A., Delmas, F., Mazzella, N., Morin, S., Daffe, G. \& Gonzalez, P., 2012. Development of q-PCR approaches to assess water quality: effects of cadmium on gene expression of the diatom Eolimna minima. Water Research 46: 934-942.

Kim Tiam, S., Morin, S., $\cdot$ Bonet, B., Guasch, H., Feurtet-Mazel, A., Eon, M., Gonzalez, P. \& Mazzella, N. 2015. Is the toxicity of pesticide mixtures on river biofilm accounted for solely by the major compounds identified? Environmental Science and Pollution Research 22: 4009-4024.

Lange-Bertalot, H., 1979. Pollution tolerance of diatoms as a criterion for water quality estimation. Nova Hedwigia, Beihefte 64: 285-304.

Larras F., Bouchez A., Rimet F. \& Montuelle B. 2012. Using Bioassays and Species Sensitivity Distributions to Assess Herbicide Toxicity towards Benthic Diatoms. PLoS ONE 7 (8), e44458. doi:10.1371/journal.pone.0044458.

Leśniewska, M. \& Witak, M. 2011. Diatoms as indicators of eutrophication in the SW part of the Gulf of Gdańsk, the Baltic Sea. Oceanological and Hydrobiological Studies 40: 68-81.

Long, E. R., MacDonald, D. D., Smith, S. L. \& Calder, F. D. 1995. Incidence of adverse biological effects within ranges of chemical concentrations in marine and estuarine sediments. Environmental Management 19: 81-97.

McCune, B. \& Mefford, M. J. 2011. PC-ORD. Multivariate Analysis of Ecological Data. Version 6. MjM Software, Gleneden Beach, Oregon, U.S.A., 28 pp. 
Medley, C.N. \& Clements, W.H. 1998. Responses of diatom communities to heavy metals in streams: the influence of longitudinal variation. Ecological Applications 8:631-644.

Moisset, S., Kim Tiam, S., Feurtet-Mazel, A., Morin, A., Delmas, F., Mazzella, N. \& Gonzalez, P. 2015. Genetic and physiological responses of three freshwater diatoms to realistic diuron exposures. Environmental Science Pollution Research 22: 4046-4055.

Moreno-Garrido, I., Hampel, M., Lubián, LM, \& Blasco J. 2003. Sediment toxicity tests using benthic marine microalgae Cylindrotheca closterium (Ehrenberg) Lewin and Reimann (Bacillariophyceae). Ecotoxicology and Environmental Safety 54: 290-295.

Moreno-Garrido, I., Lubián, L.M., Jiménez, B., Soares, A.M.V.M. \& Blasco, J. 2007. Estuarine sediment toxicity tests on diatoms: sensitivity comparison for three species. Estuarine, Coastal and Shelf Science 71: 278-286.

Morin, S., Corcoll, N., Bonet, B., Tlili, A. \& Guasch, H. 2014. Diatom responses to zinc contamination along a Mediterranean river. Plant Ecology and Evolution 147: 325-332.

Morin, S., Proia, L., 'Ricart, M.,' Geiszinger, A., ' Ricciardi, F., ' Guasch, H., ' Romani, A.M. \& Sabater S. 2010. Effects of a bactericide on the structure and survival of benthic diatom communities. Vie et Milieu 60: 107-114.

Morin, S., Cordonier, A., Lavoie, I., Arini, A., Blanco, S., Thuy Duong, T., Torne's, E., Bonet, B., Corcoll, N., Faggiano, L., Laviale, M., Pérès, F., Becares, E., Coste, M., Feurtet-Mazel, A., Fortin, C., Guasch, H. \& Sabater, S. 2012. Consistency in Diatom Response to MetalContaminated Environments. In Guasch, H. et al. (Eds.), Emerging and Priority Pollutants in Rivers, Hdb Env Chem. Springer-Verlag Berlin Heidelberg, pp. 117-146.

Pérès, F., Coste_, M. Ribeyre, F., Ricard, M. \& Boudou, A. 1997. Effects of methylmercury and inorganic mercury on periphytic diatom communities in freshwater indoor microcosms. Journal of Applied Phycology 9: 215-227,

Rabalais, N.N., Turner, R.E., Justić, D., Dortch, Q., Wiseman, W.J. \& Sen-Gupta, B.K. 1996. Nutrient changes in the Mississippi River and system responses on the adjacent continental shelf. Estuaries 19: 386-407.

Ricart, M., Guasch, H., Barceló, D., Brix, R., Maria H. Conceição, N.H., Geiszinger, A., López de Alda, M.J., López-Doval, J.C., Muñoz, I., Postigo, C., Romaní, A.M., Villagrasa, M. \& Sabater, S. 2010. Primary and complex stressors in polluted mediterranean rivers: Pesticide effects on biological communities. Journal of Hydrology 383: 52-61.

Ricciardi, F., Bonnineau, C., Faggiano, L., Geiszinger, A., Guasch, H., Lopez-Doval, J., Muñoz, I., Proia, L., Ricart, M., Romaní, A., Sabater, S. 2009. Is chemical contamination linked to the diversity of biological communities in rivers? Trends in Analytical Chemistry 28: 592-602. 
Sabater, S. 2000. Diatom communities as indicators of environmental stress in the Guadiamar River, S-W. Spain, following a major mine tailings spill. Journal of Applied Phycology 12: 113124.

Smol, J.P. \& Stoermer, E.F. 2010. The Diatoms: Applications for the Environmental and Earth Sciences, Second Edition. Cambridge University Press, 667 p.

Spencer, P., Bowman, M.F. \& Dubé, M.G. 2008. A multitrophic approach to monitoring the effects of metal mining in otherwise pristine and ecologically sensitive rivers in Northern Canada. Integrated Environmental Assessment and Management 4: 327-343.

Varekamp, J.C., Thomas, E., Altabet, M., Cooper, S. \& Brinkhuis, H. 2010. Environmental Change in Long Island Sound in the Recent Past: Eutrophication and Climate Change. Final report LISRF grant \#CWF 334-R. E\&ES Wesleyan University, CT.

Weckström, K. \& Juggins, S. 2006. Coastal diatom-environment relationships from the Gulf of Finland, Baltic Sea. Journal of Phycology 42: 21-35.

Ter Braak, C.J. F. \& Šmilauer, P. 2012. CANOCO reference manual and user's guide. Software for ordination (version 5.0). Biometris, Wageningen and České Budějovice, 496 pp.

Table 1. Salinity, TOC, $\%$ gravel + sand and concentrations of selected contaminants in 50 surface sediment samples.

\begin{tabular}{llll}
\hline Constituent & Min & Average & Max \\
\hline Salinity, psu & 7 & 29 & 36 \\
TOC, mg/kg & 1,100 & 10,315 & 40,000 \\
Gravel + sand, \% & 28 & 68 & 97 \\
Total PAH, $\mu \mathrm{g} / \mathrm{kg}$ & 7.6 & 468.4 & 6766.1 \\
$\mathrm{Ag}, \mathrm{mg} / \mathrm{kg}$ & $<0.1$ & 0.4 & 2.5 \\
$\mathrm{As}, \mathrm{mg} / \mathrm{kg}$ & $<0.1$ & 7.6 & 36.9 \\
$\mathrm{Cd}, \mathrm{mg} / \mathrm{kg}$ & $<0.1$ & 0.35 & 3.7 \\
$\mathrm{Cr}, \mathrm{mg} / \mathrm{kg}$ & 1.2 & 45.5 & 118.3 \\
$\mathrm{Cu}, \mathrm{mg} / \mathrm{kg}$ & 0.6 & 20.4 & 132.0 \\
$\mathrm{Hg}, \mathrm{mg} / \mathrm{kg}$ & $<0.02$ & 0.2 & 1.1 \\
$\mathrm{Ni}, \mathrm{mg} / \mathrm{kg}$ & $<0.1$ & 13.5 & 81.4 \\
$\mathrm{~Pb}, \mathrm{mg} / \mathrm{kg}$ & $<5$ & 33.8 & 250.5 \\
$\mathrm{Zn}, \mathrm{mg} / \mathrm{kg}$ & 2.6 & 89.5 & 861.0 \\
\hline
\end{tabular}


Table 2. Percent explained variation in diatom data (TVE) by individual environmental variables in CCA analyses and significance of the first CCA axes. Only those variables that had P-value below 0.01 and summary variables (CCU and $\mathrm{PAH})$ are shown.

\begin{tabular}{llll}
\hline Variable & TVE & F-ratio & p-value \\
\hline Thallium & 5.27 & 2.5 & 0.001 \\
Cobalt & 4.69 & 2.2 & 0.001 \\
Strontium & 4.41 & 2.1 & 0.001 \\
Barium & 4.24 & 2.0 & 0.002 \\
Titanium & 4.16 & 2.0 & 0.002 \\
Beryllium & 4.04 & 1.9 & 0.005 \\
Aluminum & 3.97 & 1.9 & 0.006 \\
CCU & 2.64 & 1.2 & 0.135 \\
PAH total & 2.77 & 1.3 & 0.105 \\
\hline
\end{tabular}


Table 3. Indicator values of diatom species in relation to selected contaminants. Only species with indicator values above 50 for at least one contaminant and significant at $p<0.05$ are shown. Sensitive species are those with the highest indicator values in groups of samples with relatively low contaminant concentrations; tolerant species have the highest indicator values in groups of samples with relatively high contaminant concentrations.

\begin{tabular}{|c|c|c|c|c|c|c|c|c|c|c|}
\hline Species & PAH & Ag & As & Cd & $\mathrm{Cr}$ & $\mathbf{C u}$ & Ni & Zn & $\mathrm{Hg}$ & $\mathbf{P b}$ \\
\hline \multicolumn{11}{|l|}{ Sensitive species } \\
\hline Adlaphia sp. 3 & 60 & & & & & & & & & \\
\hline Amphora sp. 1 & 54 & 57 & 48 & 53 & 59 & 58 & 63 & 53 & 54 & 47 \\
\hline Amphora sp. 2 & & 70 & & 72 & 66 & 76 & 66 & 70 & & 68 \\
\hline $\begin{array}{l}\text { Amphococconeis } \\
\text { disculoides }\end{array}$ & 69 & & & 59 & & & & & & \\
\hline Cocconeis sigillata & & 40 & & 40 & & & & & & \\
\hline Cocconeis stauroneiformis & & 62 & & 70 & 65 & 63 & 63 & 71 & & 60 \\
\hline Fallacia amphipleuroides & & 58 & & & 58 & 65 & 60 & & & 56 \\
\hline Fallacia margino-punctata & 66 & 51 & & 58 & & & & & & \\
\hline Navicula perminuta & & & 69 & & & 64 & & & & \\
\hline Planothidium delicatulum & & 66 & & 64 & 69 & & 67 & 63 & 63 & \\
\hline $\begin{array}{l}\text { Pseudostaurosira } \\
\text { perminuta }\end{array}$ & & & & & & & 49 & 53 & & \\
\hline \multicolumn{11}{|l|}{ Tolerant species } \\
\hline Berekeleya rutilans & & 53 & & 45 & 52 & & & & & \\
\hline Chaetoceros spp. & & 58 & & 65 & 59 & 67 & 61 & 74 & 53 & 56 \\
\hline Cyclotella atomus & 81 & 66 & 57 & 83 & 67 & 82 & 61 & 85 & 66 & 71 \\
\hline Cyclotella marina & 63 & 76 & 58 & 74 & 55 & 68 & & 60 & 59 & 61 \\
\hline Navicula gregaria & 67 & 74 & & 66 & 56 & & & & & 66 \\
\hline Navicula salinicola & 51 & & & & & & & & & \\
\hline Nitzschia sp. 3 & & 50 & & 52 & 62 & & 51 & & & \\
\hline $\begin{array}{l}\text { Pseudostaurosira cf. } \\
\text { trainorii }\end{array}$ & & & & 53 & & 44 & & 45 & & \\
\hline Skeletonema spp. & 67 & 90 & 62 & 85 & 77 & 71 & 72 & 78 & 68 & 70 \\
\hline Thalassiosira incerta & & & & 57 & 41 & & 49 & & & \\
\hline Thalassiosira proschkinae & & & 56 & & & & & & & \\
\hline Thalassiosira sp. 2 & & & & & 52 & & 48 & & & \\
\hline
\end{tabular}




\section{Figure captions}

Figure 1. Map of the study area showing sampling locations.

Figure 2. PCA biplot showing environmental parameters (arrows) and sample centroids (circles). Individual PAH species are all highly correlated and grouped under the name "PAH". CCU cumulative criterion unit, a compound variable reflecting concentrations of nine metals. CCU and total PAH were used as passive variables as they represent combinations of several other variables included in the analysis.

Figure 3. DCA biplot showing passive environmental parameters (arrows) and species centroids (triangles). Only species with 20-100\% weight are displayed. Species codes in this and further ordination plots are: ADL3- Adlaphia sp. 3, AMPCdisc-Amphicocconeis disculoides (Hustedt) De Stefano \& Marino, AMPHpusi - Amphora pusilla Gregory, AMPH1 - Amphora sp. 1, AMPH - Amphora sp. 2, CATEadl - Catenula adherens Mereschkowsky, CHAEspp Chaetoceros spp., COCCline- Cocconeis placentula var. lineata (Ehrenberg) Van Heurck, COCCneom - Cocconeis neothumensis var. marina De Stefano et al., COCCstau - Cocconeis stauroneiformis (W. Smith) H. Okuno, CYCLatom - Cyclotella atomus Hustedt, CYCLchoc Cyclotella choctawhatecheeana Prasad, CYCLmari - Cyclotella marina (Tanimura et al.) AkéCastillo et al., CYMAbelg - Cymatosira belgica Grunow, DELPminu - Delphineis minutissima (Hustedt) Simonsen, DENTsubt - Denticula subtilis Grunow, FALLamph - Fallacia amphipleuroides (Hustedt) D.G. Mann, FALLmarg - Fallacia margino-punctata Sabbe \& Vyverman, FALL18 - Fallacia sp. 18, FRAGcass - Fragilaria cassubica Witkowski \& LangeBertalot, HALAapon - Halamphora aponina (Kützing) Levkov, MADflex - Madinithidium flexuistriatum (Riaux-Gobin at al.) Witkowski et al., MINIspp - Minidicus spp., NAVgreg Navicula gregaria Donkin, NAVperm - Navicula perminuta Grunow, NAVphyll - Navicula phyllepta Kützing, NAVpssal - Navicula pseudosalinarioides Giffen, NAVslncl - Navicula salinicola Hustedt, NAVvimi - Navicula viminoides Giffen, NAV2 - Navicula sp.2, NAV26 Navicula sp.26, NAV102 - Navicula sp.102, NITincon - Nitzschia inconspicua Grunow, NIT3 Nitzschia sp.3., OPE2 - Opephora sp. 2, OPE3 - Opephora sp. 3, PLANdeli - Planothidium delicatulum (Kützing) Round \& Bukhtiyarova, PLANdepe - Planothidium deperditum (Giffen) Witkowski, PLANrodr - Planothidium rodriguense Riaux-Gobin \& Compère, PLAN11 Planothidium sp. 11, PSAMvigo -Psammogramma vigoensis Sato \& Medlin, PSSTperm Pseudostaurosira perminuta (Grunow) Sabbe \& Vyverman, PSSTtrai - Pseudostauroisra trainorii Morales, SKELspp. - Skeletonema spp., THALnitz - Thalassionema nitzschioides (Grunow) Mereschkowsky, THALpros - Thalassiosira proschkinae Makarova, THAL3 Thalassiosira sp. 3.

Figure 4. Species-environmental variables biplot resulting from the CCA with two constraining variable, CCU and PAH and three covariates, salinity, grain size, and TOC. Only species with $20-100 \%$ weight are displayed. Species codes are as in Fig. 3.

Figure 5. Mean relative abundance of the diatom species plotted against species scores along the first RDA axis with bottom/top sample position as a single constraining variable. Only species with more than $1 \%$ mean relative abundance in the dataset are shown. Species codes are as in Fig.3. Species with significant at $p<0.05$ level indicator values in relation to contaminants are shown ether by red stars (increased abundance in contaminated sediments) or by green down- 
triangles (decreased abundance in contaminated sediments). Most species sensitive to contaminants were more abundant in bottom samples, while most tolerant species increased their abundance towards the top sediment layers. 


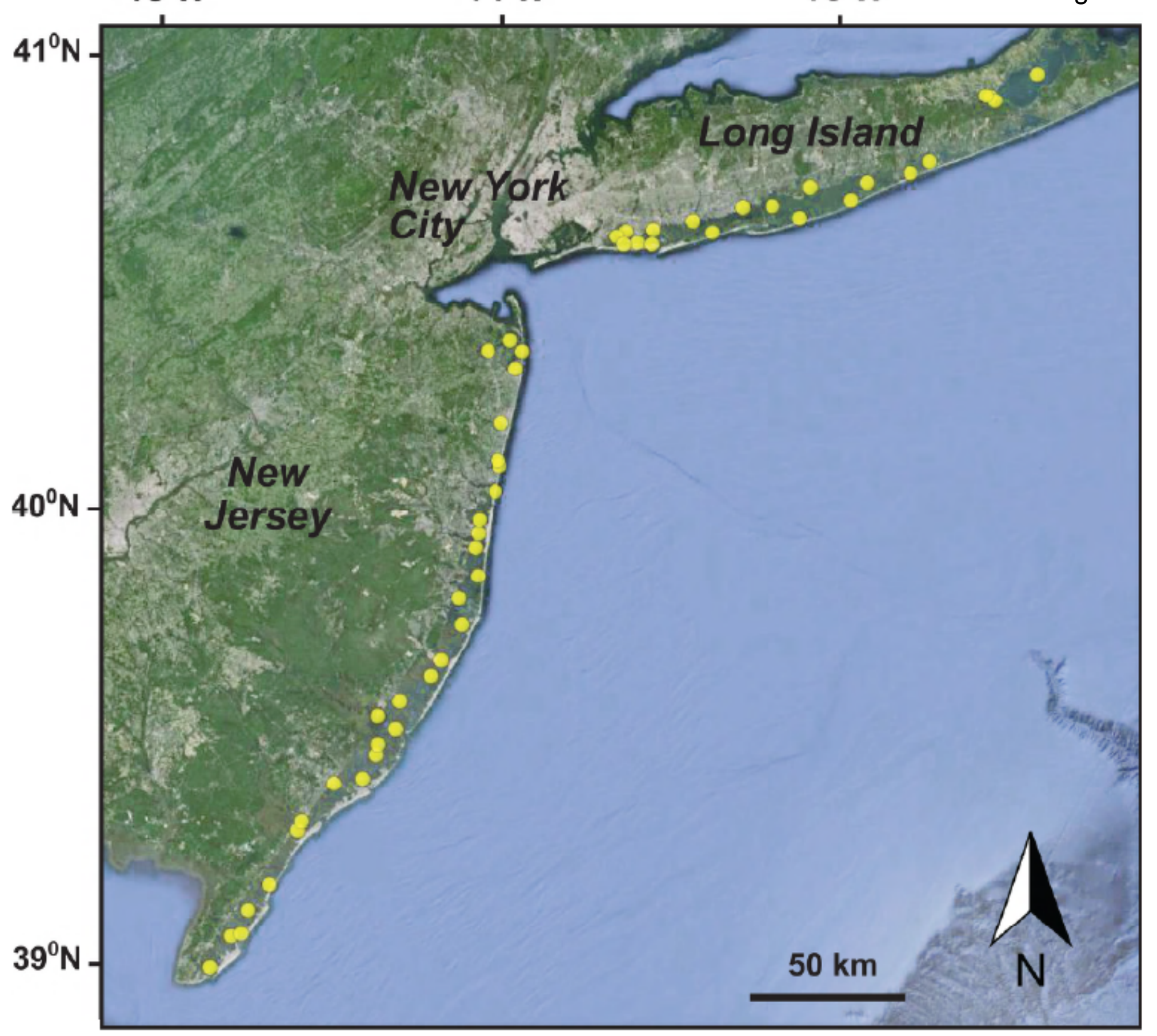




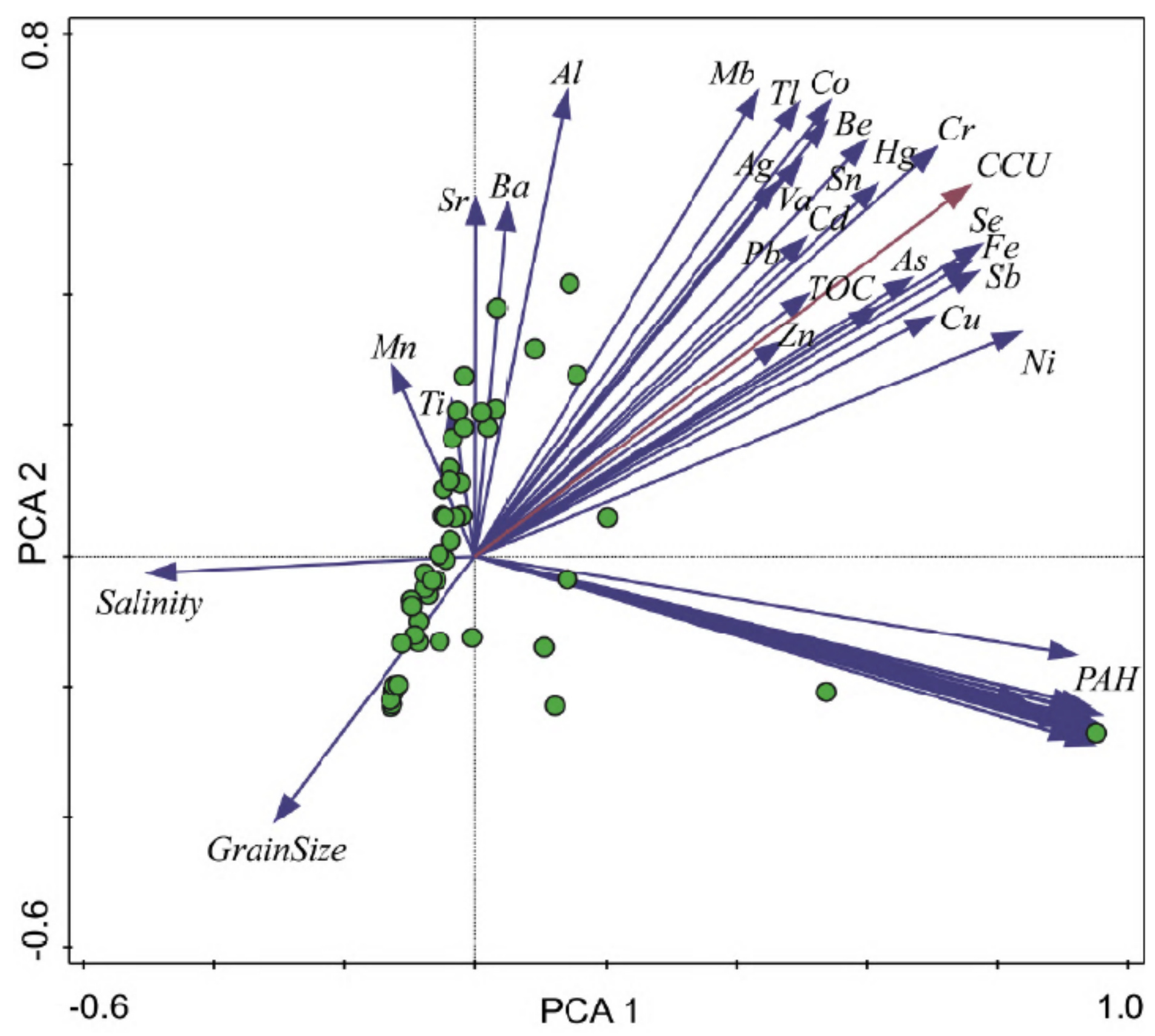

Figure 2 


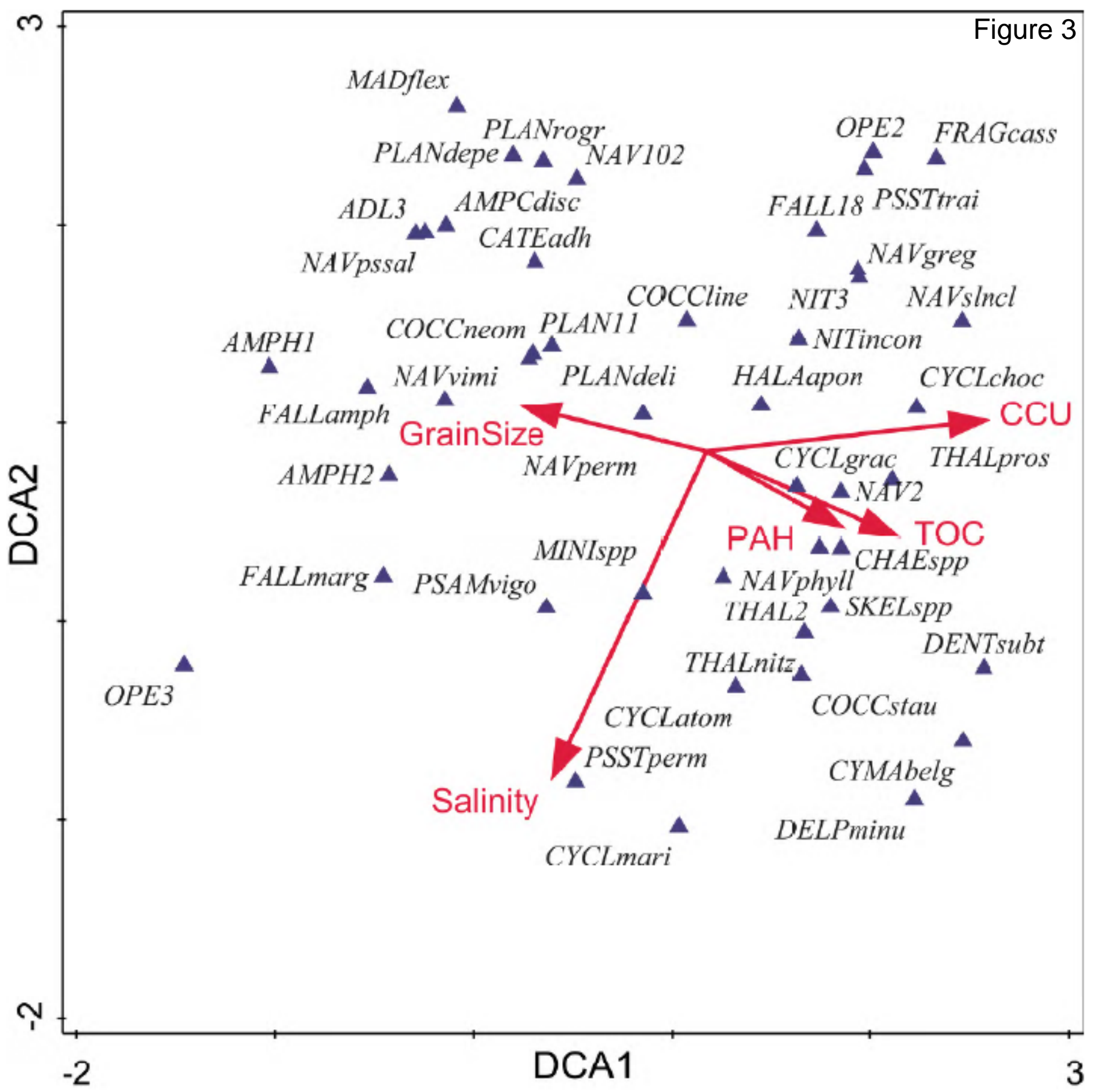




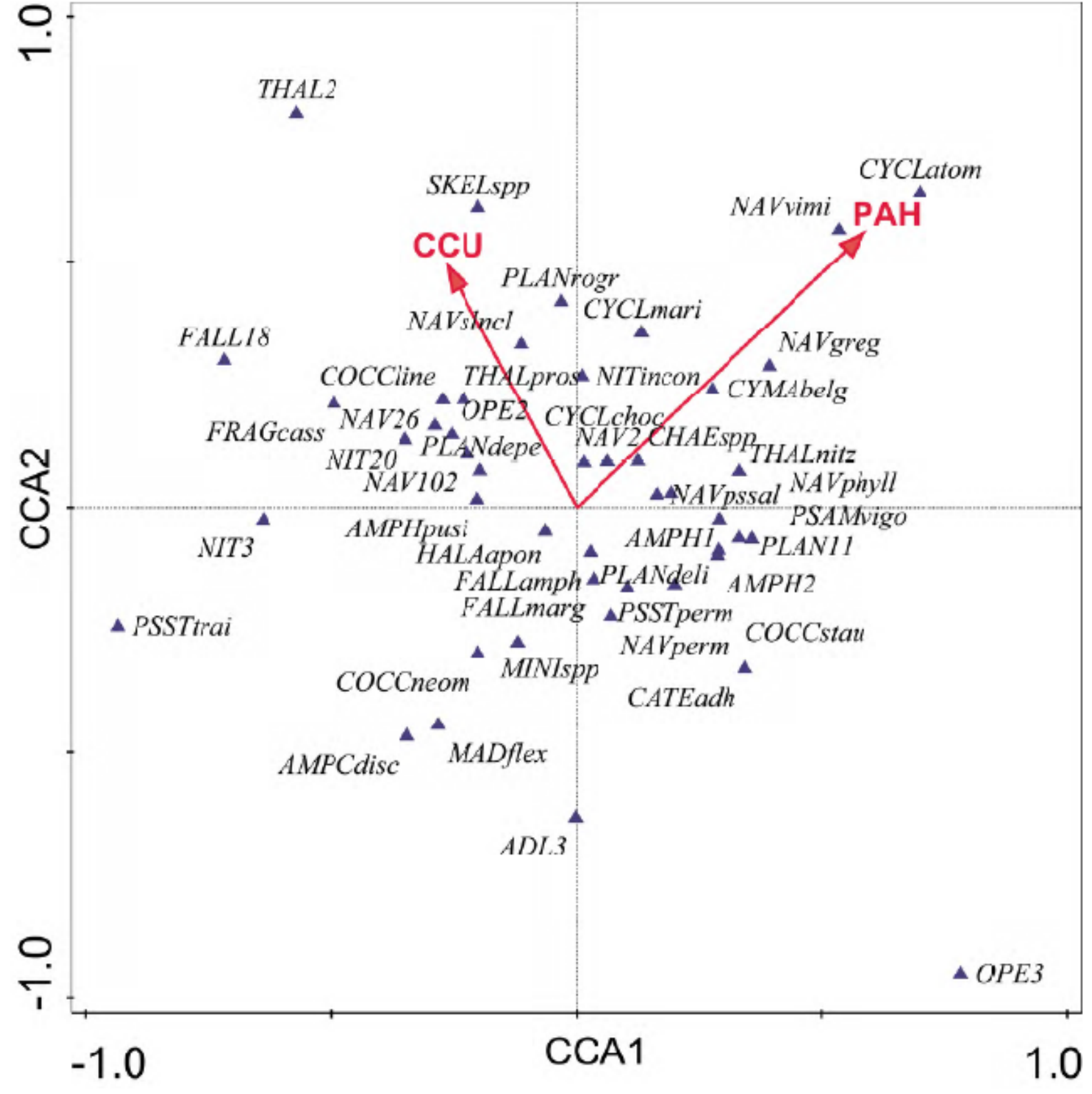

Figure 4 


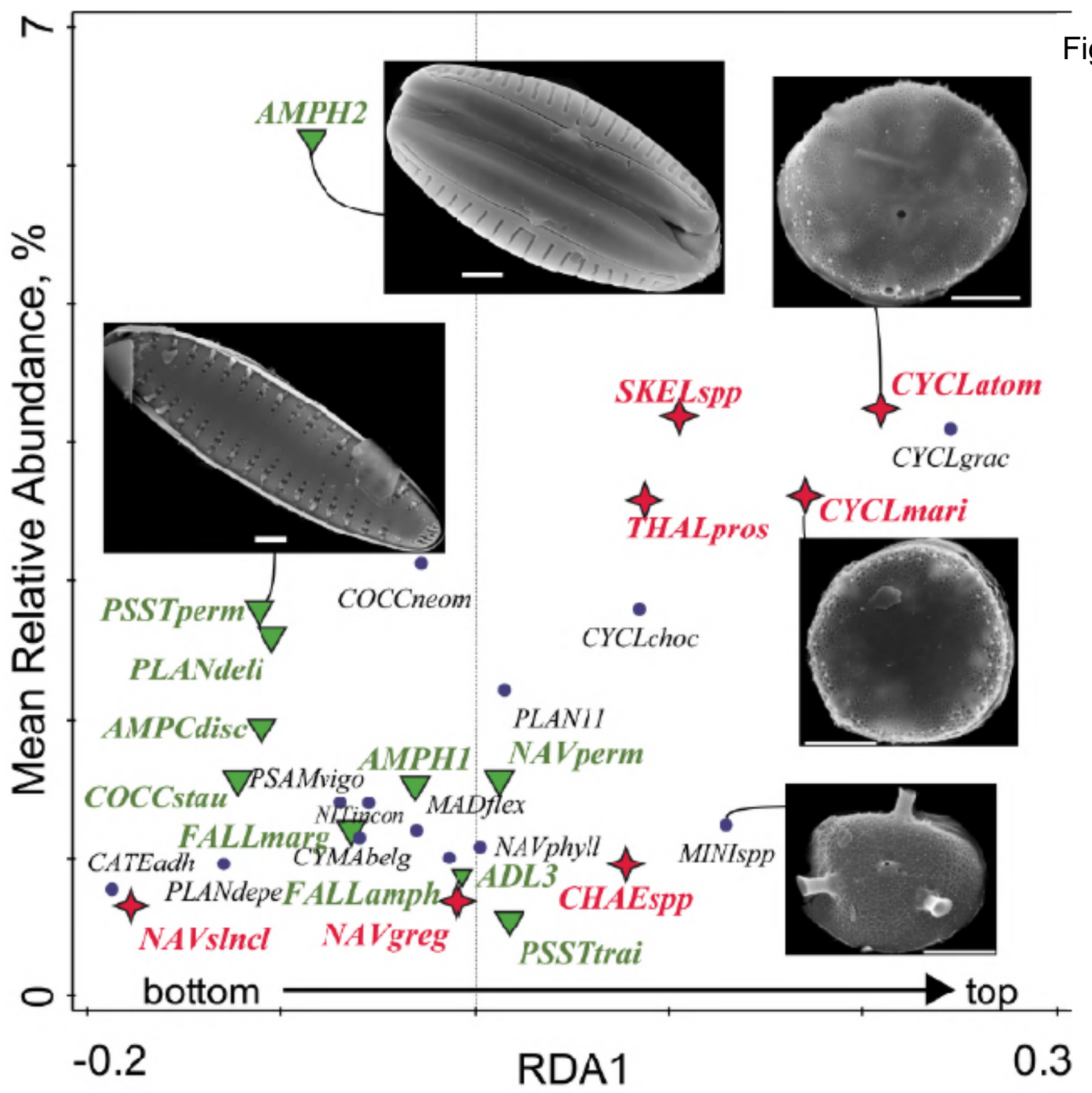

Figure 5 